\title{
SATISFACTION WITH HEALTHCARE: THE CHANGES AND FEATURES OF PATIENTS MAKING AKNOWLEDGEMENTS FOR DOCTORS AND NURSES WIEWS
}

\author{
Vinsas Janušonis \\ Klaipeda University, Klaipeda University Hospital, Lithuania
}

Key words: healthcare quality, patients satisfaction, healthcare assessment, patients' thanks for medics.

\section{Summary}

The aim of the study - to estimate patients, who gave thanks for medics - doctors and nurses opinion changes and singularity of right healthcare, satisfaction and fruition their expectations.

Material and methods. From January 2004 to December 2015 a survey was performed in Klaipeda University Hospital (KUH). The study included 197755 patients who were undergoing treatment in KUH.

Information was collected via questionnaires (response rate $81,4 \%$ ).

The patients who gave thanks for medics group was analyzed apart. The survey was analyzed and compared for the periods 2004-2006 and 2013-2015.

Results and discussion. The most part of patients who gave thanks for medics was aged 50-69 (15, $8 \%$ ), at work, women. The time of healthcare services, information for patients, good contact and communication between patients and medics, patients' satisfaction influenced the number of thanks. The number of thanksgiving have not direct correlation with healthcare quality.

Conclusions. Patients thanksgiving has confirmed the KUH provided healthcare for the majority of patients are appropriate to meet their expectations and they are satisfied with it.

Comparison of both analyzed periods has shown that over 10 years fell acknowledgments for medics. Age, gender and social status had the impact on the number of acknowledgments - more thanksgiving was from women, patients 50-59 year age, retired and persons with disabilities.

The right cooperation between medics and patients, provision of healthcare information to patients in- creased the number of thanksgiving.

The number of patients who satisfied with healthcare results and meet their expectations directly correlated with number of patients who gave thanks for medics.

\section{Introduction}

The survey of patients' opinion on the day of discharge out of the hospital is a widespread and informative.

Patients' opinion and healthcare assessment becomes a necessary attribute of healthcare organizations, it is provided for in law in many countries.

Patients' opinion and healthcare assessment initiates the changes in healthcare organizations and systems. Patients opinion fully or fragmented reflect their expectations and satisfaction.

The essential patients expectation - personalize, secure and effective healthcare (1). They are materialized through the patients' perception of healthcare quality, their knowledge, experience, and information. Patients satisfaction is the important part of healthcare quality management reflecting the patients' needs and expectations and medics' possibility to meet them.

Patient satisfaction of healthcare is difficult to measure and to explore because it is a phenomenon with many components. It depends not only on medics, patients and organizations, but also on healthcare system and environment.

The patients' satisfaction source are fragmented and depends not only on medics. The environment, social - economics factors, patients' personal characteristics influence patients' satisfaction, although the lack of clear mechanism and degree of satisfaction $(3,4)$.

Patients opinion, degree and fragmentation of satisfaction are subjective and depends on the subjective circumstances - from its assessment of health status to episode of hospitalization (5).

Patients acknowledgement as expression of satisfaction depends on personal characteristics - age, education, sex, 
race, ethnic group, family and social status and others. The younger and older than 65 years patients less often tend to give thanks for medics $(7,8)$. The concept of healthcare quality, perceptions and assessment of results in each age group is different.

Patients-medics communication, information on healthcare, its timeliness and privacy, trust and the degree of expectations determines patients' satisfaction.

The brightest expression of satisfaction - thanks for medics, the decision choose the same hospital and medics, recommend it to others.

Patient - medics communication as factor of satisfaction is very important.

Here nurses have more important role than doctors they meet with patients, answer their questions and solves problems much more often $(9,10)$.

While communication is important throughout the all healthcare process, however, patients highlight time of hospitalization and discharge from hospital (11).

Considerable influence on the patients' satisfaction have "hotel" services in the hospital - room, hygiene, food. Three levels of patients' satisfaction are marked (12): the first - when meet the base needs of patients, the second when the service provides satisfaction, and third - when the service provides delight and admiration.

Patients, who are satisfied with the services in healthcare organization(HCO) do not always meet her next time and the expectations exceeded ones whose - almost always opt for' the same (13). These patients remaining in the received message of thanks to express in writing.

Patients' thanks for medics are the highest expression of their satisfaction perceived through their concept of quality healthcare, medics - patients relations and verification their expectations.

The process of healthcare episode in hospital for patients' is one whole.

As a result, thanksgiving reflects the level of HCO performance quality and partly - the level of healthcare quality.

The research of patients' satisfaction on healthcare help improve practice and quality of healthcare in hospitals.

The aim of the study - to estimate patients who gave thanks for medics - doctors and nurses opinion changes and singularity of right healthcare, satisfaction and fruition their expectations.

\section{Material and methods}

The population of the study - inpatients of Klaipeda University Hospital (KUH).

The objects of the study - patients who gave thanks for medics opinion about healthcare episode in hospital (from hospitalization to discharge).

The concept "medics" includes all physicians and nurses.

Methods - the analysis of literary and the prospective survey questionnaire, statistical grouping, comparative content analysis.

For study used the questionnaire created by author (with contributor). The questionnaire was completed by patients or their relatives after healthcare episode in hospital.

The questionnaire was drawn up considering patients perception of component of healthcare quality (16-18), the patients' rights and compensation for damage to health law (19), the European Charter of patients' rights (20).

The questionnaire consists of 21 main question, one of which is the open type.

From January 2004 to December 2015 a survey was performed in KUH. The study included 197755 patients who were undergoing treatment in KUH. Information was collected via questionnaires (response rate 81, 4\%).

The survey data was analyzed and compared for the periods 2004-2006 ad 2013-2015 according to their age, sex, social status, access to the hospital way.

Patients are divided in to four representative age groups - up to 29 years (a), 30-49 years (b), 50-69 years (c), and over the 70 years (d).

According to patients social (working) status has been identified workers, unemployed, the retired and the disabled, and students (children) groups. The statistically significant difference of age, sex, socially status, between the periods were analyzed no observed.

The respondents represent a sample of large multiprofile hospitals' in patients.

The statistical analysis of the data was performed by using the ,,SPSS 17, 0.1 for Windows “ and ",Microsoft Office Excel 2003 “ programmes. The significance of statistical data was verified by criteria of "Student" and "Pearson $\mathrm{x}^{2 "}$, and Spearman coefficient.

The difference between the data was statistically significant when $\mathrm{p}<0,05$.

The methodological limitations of the study. The only inpatients was explored. For the elderly patients (more than 70 years age) may be difficult to read and understand questionnaire, write thanks so such data of questionnaires may not be as accurate.

For comparison with other literature sources, very important structure of the hospitals where study carried out. The clinical profile of the hospitals (oncology, rehabilitation, psychiatry, surgery, nursing and others) determine the patients satisfaction. 
Table 1. The distribution of patients, who gave thanks for medics, by age and gender

* The rest your age and gender didn 't indicate

\begin{tabular}{|c|c|c|c|c|c|c|c|c|c|c|c|c|c|c|c|c|c|c|c|}
\hline \multicolumn{20}{|c|}{ 2004-2006 yr. } \\
\hline \multicolumn{4}{|c|}{$\begin{array}{l}\text { Up to } 29 \mathrm{yr} \\
\mathrm{n}=24331\end{array}$} & \multicolumn{4}{|c|}{$\begin{array}{l}30-49 \mathrm{yr} . \\
\mathrm{n}=20622\end{array}$} & \multicolumn{4}{|c|}{$\begin{array}{l}\text { 50-69 yr. } \\
\mathrm{n}=21534\end{array}$} & \multicolumn{4}{|c|}{$\begin{array}{c}70 \mathrm{yr} \text {. and }> \\
\mathrm{n}=16226\end{array}$} & \multicolumn{4}{|c|}{$\begin{array}{c}\text { Total } \\
\mathrm{n}=\mathbf{8 2 7 1 3}\end{array}$} \\
\hline \multicolumn{2}{|c|}{$\begin{array}{c}\mathrm{f} \\
\mathrm{n}=19075\end{array}$} & \multicolumn{2}{|c|}{$\begin{array}{c}\mathrm{m} \\
\mathrm{n}=5256\end{array}$} & \multicolumn{2}{|c|}{$\begin{array}{c}\mathrm{f} \\
\mathrm{n}=14503\end{array}$} & \multicolumn{2}{|c|}{$\begin{array}{c}\mathrm{m} \\
\mathrm{n}=6119\end{array}$} & \multicolumn{2}{|c|}{$\begin{array}{c}\mathrm{f} \\
\mathrm{n}=12379\end{array}$} & \multicolumn{2}{|c|}{$\begin{array}{c}\mathrm{m} \\
\mathrm{n}=9155\end{array}$} & \multicolumn{2}{|c|}{$\begin{array}{c}\mathrm{f} \\
\mathrm{n}=10647\end{array}$} & \multicolumn{2}{|c|}{$\begin{array}{c}\mathrm{m} \\
\mathrm{n}=5579\end{array}$} & \multicolumn{2}{|c|}{$\begin{array}{c}\mathrm{f} \\
\mathrm{n}=56604\end{array}$} & \multicolumn{2}{|c|}{$\begin{array}{c}\mathrm{m} \\
\mathrm{n}=26109\end{array}$} \\
\hline \multicolumn{2}{|c|}{ Gave thanks } & \multicolumn{2}{|c|}{ Gave thanks } & \multicolumn{2}{|c|}{ Gave thanks } & \multicolumn{2}{|c|}{ Gave thanks } & \multicolumn{2}{|c|}{ Gave thanks } & \multicolumn{2}{|c|}{ Gave thanks } & \multicolumn{2}{|c|}{ Gave thanks } & \multicolumn{2}{|c|}{ Gave thanks } & \multicolumn{2}{|c|}{ Gave thanks } & \multicolumn{2}{|c|}{ Gave thanks } \\
\hline $\mathrm{n}$ & $\%$ & $\mathrm{n}$ & $\%$ & $\mathrm{n}$ & $\%$ & $\mathrm{n}$ & $\%$ & $\mathrm{n}$ & $\%$ & $\mathrm{n}$ & $\%$ & $\mathrm{n}$ & $\%$ & $\mathrm{n}$ & $\%$ & $\mathrm{n}$ & $\%$ & $\mathrm{n}$ & $\%$ \\
\hline 1952 & 10,2 & 348 & 6,6 & 2619 & 18,1 & 830 & 13,6 & 2567 & 20,7 & 1167 & 12,7 & 1364 & 12,8 & 598 & 10,7 & 8502 & 15,0 & 2943 & 11,3 \\
\hline \multicolumn{4}{|c|}{$\begin{array}{c}\text { Total } \\
2300(9,5 \%)\end{array}$} & \multicolumn{4}{|c|}{$\begin{array}{c}\text { Total } \\
8449(16,7 \%)\end{array}$} & \multicolumn{4}{|c|}{$\begin{array}{c}\text { Total } \\
3734(17,3 \%) \\
\end{array}$} & \multicolumn{4}{|c|}{$\begin{array}{c}\text { Total } \\
1962(12,1 \%)\end{array}$} & \multicolumn{4}{|c|}{$\begin{array}{c}\text { Total } \\
11445(13,8 \%)\end{array}$} \\
\hline \multicolumn{20}{|c|}{ 2013-2015 yr. } \\
\hline & $\begin{array}{r}\text { Up t } \\
\mathbf{n}=2\end{array}$ & 957 & & & $\begin{array}{l}30- \\
n=2\end{array}$ & & & & & & & & $\begin{array}{r}70 \mathrm{~m} \cdot \mathrm{y} \\
\mathrm{n}=2\end{array}$ & $\begin{array}{l}\text { and }> \\
159\end{array}$ & & & $\begin{array}{r}T \\
n=10\end{array}$ & al $94 *$ & \\
\hline & & & & & & & & $\mathrm{n}=1$ & & & & & & & & & & & \\
\hline Gave & hanks & Gav & lanks & Gave & hanks & Gav & hanks & Gave & hanks & Gave & hanks & Gave & hanks & Gav & hanks & Gave & hanks & Gave & lanks \\
\hline $\mathrm{n}$ & $\%$ & $\mathrm{n}$ & $\%$ & $\mathrm{n}$ & $\%$ & $\mathrm{n}$ & $\%$ & $\mathrm{n}$ & $\%$ & $\mathrm{n}$ & $\%$ & $\mathrm{n}$ & $\%$ & $\mathrm{n}$ & $\%$ & $\mathrm{n}$ & $\%$ & $\mathrm{n}$ & $\%$ \\
\hline 819 & 4,4 & 270 & 4,2 & 1492 & 7,7 & 427 & 6,5 & 2778 & 18,3 & 1074 & 9,2 & 1861 & 12,1 & 630 & 8,0 & 6950 & 10,2 & 2401 & 7,4 \\
\hline & $\begin{array}{r}\mathrm{T} \\
1089\end{array}$ & $4 \%)$ & & & $\begin{array}{r}\mathrm{T} \\
1919\end{array}$ & , $4 \%)$ & & & $\begin{array}{r}\mathrm{T} \\
3852\end{array}$ & $\begin{array}{l}\text { al } \\
4,3 \%)\end{array}$ & & & $\begin{array}{r}\mathrm{T} \\
2491(\end{array}$ &, $8 \%$ & & & 9351 & al $3 \%)$ & \\
\hline
\end{tabular}

Table 2. The distribution of patients, who gave thanks for medics, by social status and the way of access to the hospital * The rest your social (working) status and the way of access didn't indicate

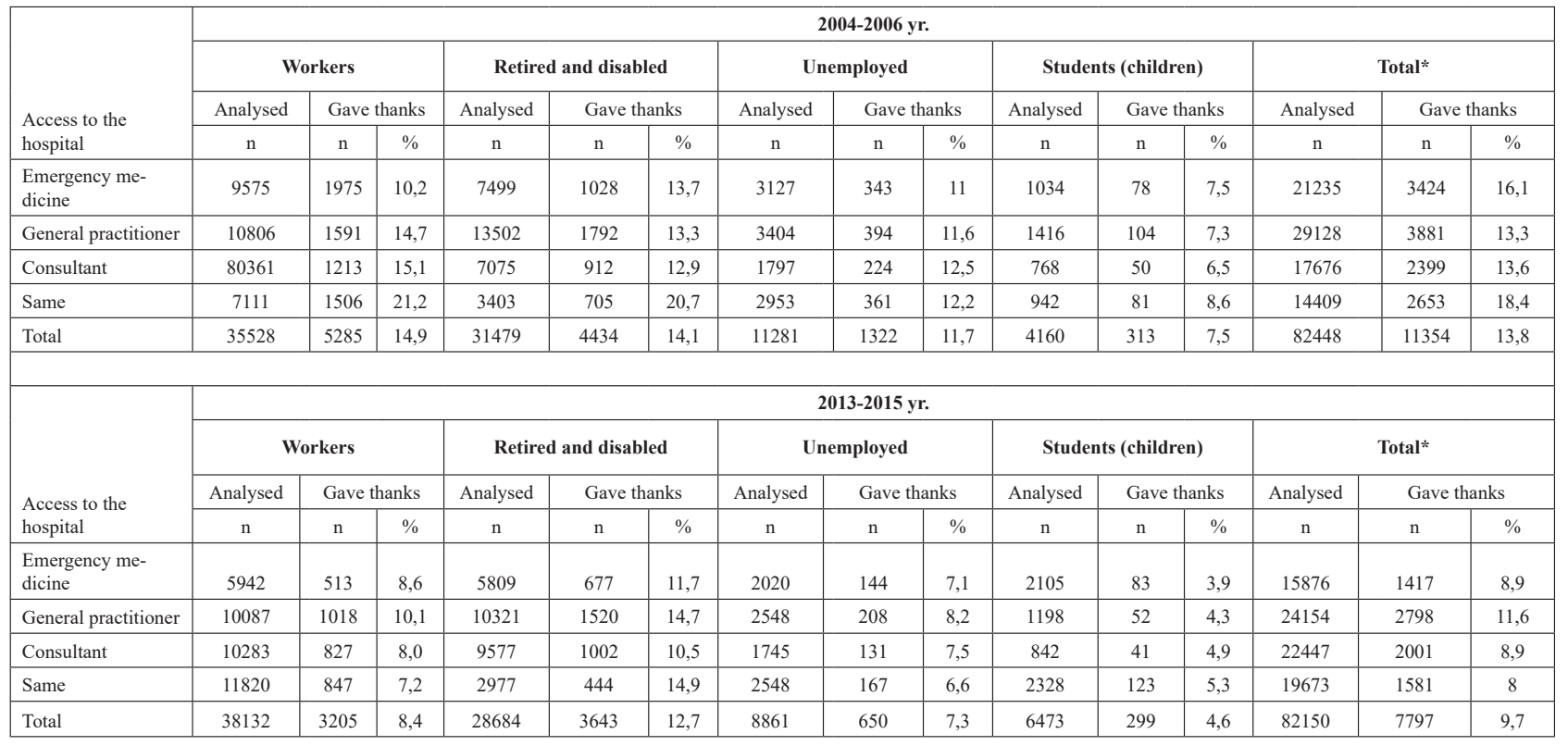

Even one-fifth $(21,8 \%)$ of the patients not replied or not fully replied to the questionnaires although data of other authors, testing the patient satisfaction are similar $(21,22)$. Every tenth $(12,1 \%)$ patient questionnaire filled the fellow
- men or relatives, which expresses not only patients, but also for its opinion. It is noted than when the questionnaire completed by fellow-men or relatives, the level of patient satisfaction is reflected lower (23). 
Table 3. The distribution of hospitalized patients, who gave thanks for medics, by time of healthcare service on the first stage of hospitalization

\begin{tabular}{|c|c|c|c|c|c|c|c|c|c|c|c|c|c|c|c|}
\hline \multicolumn{16}{|c|}{ 2004-2006 yr. } \\
\hline \multicolumn{4}{|c|}{$\begin{array}{c}\text { Examination at emergency } \\
\text { department }\end{array}$} & \multicolumn{4}{|c|}{ Access to medical unit } & \multicolumn{4}{|c|}{ Physician's examination in the room } & \multicolumn{4}{|c|}{ Start of treatment in the room } \\
\hline \multicolumn{4}{|c|}{$\mathrm{n}=\mathbf{8 3 3 3 3}$} & \multicolumn{4}{|c|}{$n=83333$} & \multicolumn{4}{|c|}{$n=83333$} & \multicolumn{4}{|c|}{$\mathrm{n}=\mathbf{8 3 3 3 3}$} \\
\hline \multicolumn{2}{|c|}{ Up to $30 \mathrm{~min}$} & \multicolumn{2}{|c|}{$\begin{array}{l}\text { After } 30 \mathrm{~min} \\
\text { or didn't poin }\end{array}$} & \multicolumn{2}{|c|}{ Up to $30 \mathrm{~min}$. } & \multicolumn{2}{|c|}{$\begin{array}{l}\text { After } 30 \text { min. } \\
\text { or didn't point }\end{array}$} & \multicolumn{2}{|c|}{ Up to $30 \mathrm{~min}$. } & \multicolumn{2}{|c|}{$\begin{array}{l}\text { After } 30 \text { min. or } \\
\text { didn't point }\end{array}$} & \multicolumn{2}{|c|}{ Up to $30 \mathrm{~min}$. } & \multicolumn{2}{|c|}{$\begin{array}{c}\text { After } 30 \text { min. or didn } \\
\text { point }\end{array}$} \\
\hline \multicolumn{2}{|c|}{$\mathrm{n}=73131$} & \multicolumn{2}{|c|}{$\mathrm{n}=10202$} & \multicolumn{2}{|c|}{$\mathrm{n}=67147$} & \multicolumn{2}{|c|}{$n=16186$} & \multicolumn{2}{|c|}{$\mathrm{n}=72030$} & \multicolumn{2}{|c|}{11303} & \multicolumn{2}{|c|}{$\mathrm{n}=67107$} & \multicolumn{2}{|c|}{$n=16226$} \\
\hline \multicolumn{2}{|c|}{ Gave thanks } & \multicolumn{2}{|c|}{ Gave thanks } & \multicolumn{2}{|c|}{ Gave thanks } & \multicolumn{2}{|c|}{ Gave thanks } & \multicolumn{2}{|c|}{ Gave thanks } & \multicolumn{2}{|c|}{ Gave thanks } & \multicolumn{2}{|c|}{ Gave thanks } & \multicolumn{2}{|c|}{ Gave thanks } \\
\hline $\mathrm{n}$ & $\%$ & $\mathrm{n}$ & $\%$ & $\mathrm{n}$ & $\%$ & $\mathrm{n}$ & $\%$ & $\mathrm{n}$ & $\%$ & $\mathrm{n}$ & $\%$ & $\mathrm{n}$ & $\%$ & $\mathrm{n}$ & $\%$ \\
\hline 17167 & 23,5 & 1290 & 12,6 & 15381 & 22,9 & 2294 & 14,2 & 16380 & 22,7 & 1295 & 11,5 & 15434 & 23 & 2241 & 13,8 \\
\hline & & & & & & & & & 3-2015 & & & & & & \\
\hline Exam & $\begin{array}{r}\text { nation } \\
\text { depa }\end{array}$ & $\begin{array}{l}\text { at em } \\
\text { rtment }\end{array}$ & gency & Acc & ess to & nedical & unit & Physici & s exan & 1ation ir & e room & & of tre & ent in the & \\
\hline & $n=1$ & 27750 & & & $\mathrm{n}=1$ & 27750 & & & $\mathbf{n}=$ & 7750 & & & & 27750 & \\
\hline Up to & $0 \mathrm{~min}$ & $\begin{array}{l}\text { After } \\
\text { or did }\end{array}$ & 0 min. & Up to & $30 \mathrm{~min}$ & $\begin{array}{l}\text { After } \\
\text { or didn }\end{array}$ & $\begin{array}{l}0 \text { min. } \\
t \text { t point }\end{array}$ & Up to & $\min$. & $\begin{array}{r}\text { After } \\
\text { didn }\end{array}$ & $\begin{array}{l}\text { min. or } \\
\text { oint }\end{array}$ & $\mathrm{Upt}$ & $\min$. & After 30 & or didn't \\
\hline $\mathrm{n}=9$ & 664 & $\mathrm{n}=$ & 086 & $\mathrm{n}=9$ & 2546 & $\mathrm{n}=3$ & 204 & & & $\mathrm{n}=$ & & & & & \\
\hline Gave & hanks & Gave & hanks & Gave & thanks & Gave & hanks & Gav & anks & Gave & anks & $\mathrm{Ga}$ & & $\mathrm{Ga}$ & anks \\
\hline $\mathrm{n}$ & $\%$ & $\mathrm{n}$ & $\%$ & $\mathrm{n}$ & $\%$ & $\mathrm{n}$ & $\%$ & $\mathrm{n}$ & $\%$ & $\mathrm{n}$ & $\%$ & $\mathrm{n}$ & $\%$ & $\mathrm{n}$ & $\%$ \\
\hline 7986 & 8,6 & 1588 & 4,5 & 7745 & 8,4 & 1819 & 5,2 & 8140 & 8,6 & 1924 & 5,8 & 7092 & 8,5 & 2472 & 5,6 \\
\hline
\end{tabular}

\section{Results and discussion}

The thanks for medics of KUH in open-type question of questionnaire stated $23347(11,8 \%)$ patients [11445 (13, $7 \%)$ in 2004-2006 and $11902(10,4 \%)$ in 2013-2015)].

The contingent of the study by sex $-15492(66,2 \%)$ were women, 5344 (22,9\%) were men, 2511 (10,9\%) didn't point your sex.

In both analyzed periods, women gave thanks for medics more often than men (statistically significant difference (SSD). In period 2004-2006 women and men gave thanks for medics more often compared with period 20132015 (Table 1).

The analysis of patients by age group showed, that the least number of thanks gave patients up to 29 year $(6,9 \%)$ and quite a number of thanks gave patients 50-69 year of age (SSD). Such a trend was in both analyzed periods.

In both analyzed periods of all age groups women gave thanks for medics more often than men. A striking difference was in 50-69 years age group $(19,5 \%$ women and $11 \%$ men). The bright fall of thanks given was in period 2013-2015 compared with period 2004-2006 in age group up to 29 year and 30-49 years (Table 1).

The situation, that less thanksgiving was from the younger and over 70 years patients complies with the data of literature (24).

The analysis of patients by social status showed that the most thanks giving for medics was from retired and disabled patients $(13,4 \%)$, the lowest - from the students (children) (6,1\%).

The part of patients who gave thanks for medics of workers was $11,7 \%$, unemployed $-9,5 \%$.

In period 2013-2015 compared with period 2004-2006 the part of patients who gave thanks for medics decreased in both analyzed groups (Table 2).

The way of access to the hospital and the circumstances of first stage of hospitalization effect patient satisfaction (25).

Comparing the survey data with the survey data of Germany hospitals (32) to KUH has got with the medical emergency $18,8 \%$ of patients (in Germany $-22,4 \%$ ), the general practionar's sending $-26,9 \%$ (in Germany $-30,5 \%$ ), from the consultants $-20,3 \%$ (in Germany $-40,2 \%$ ), arrived of 
Table 4. The distribution of hospitalized patients, who gave thanks for medics, depending on the information and communication with patients

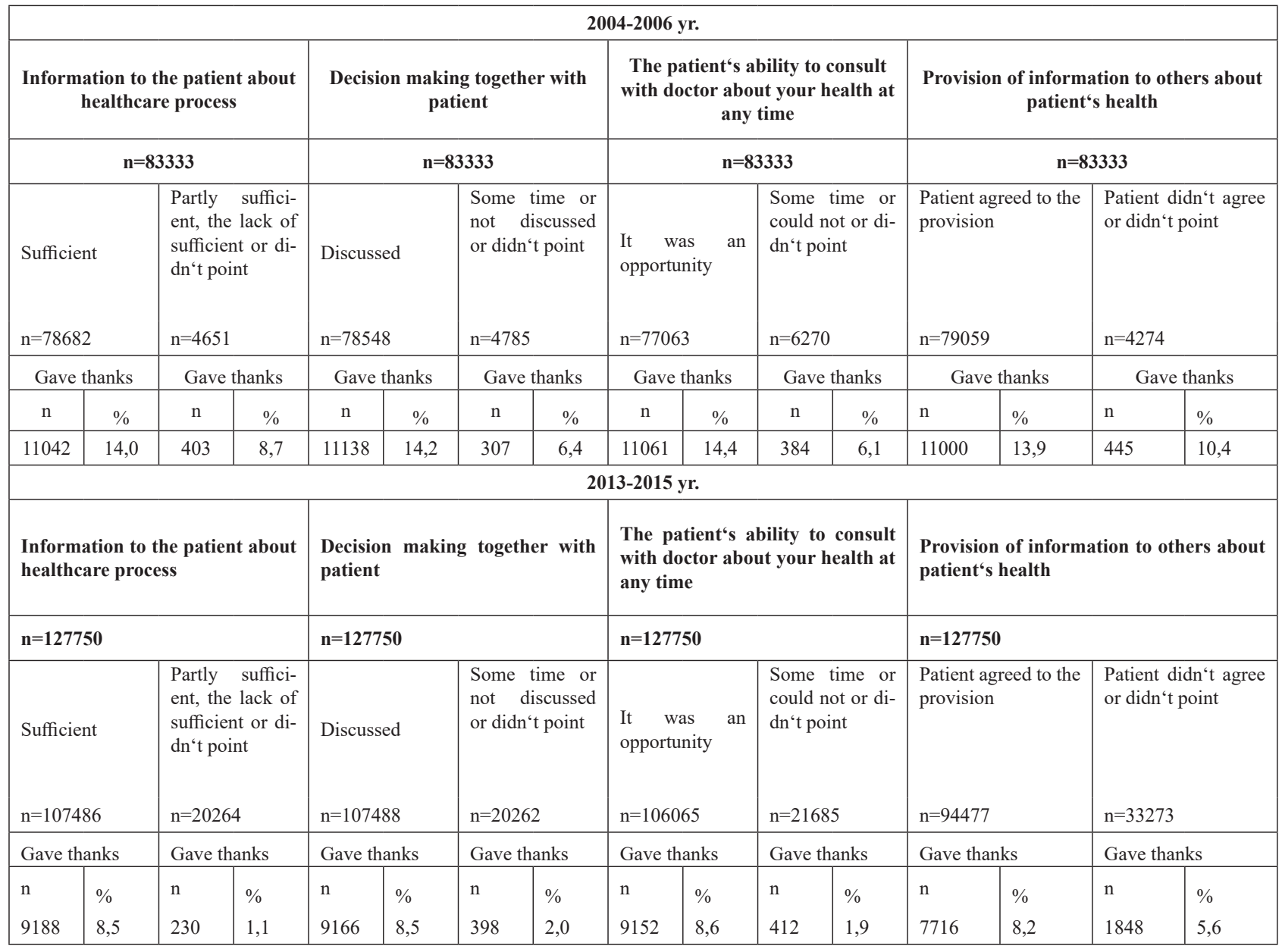

the same $-17,2 \%$ (in Germany - 5,6\%), didn't point or didn't respond $-16,8 \%$ (in Germany - 0,1\%).

The analysis of patients who gave thanks for medics in accordance with the way of access to the hospital showed that this not affect patients opinion.

In period 2013-2015 compared with period 2004-2006 the part of patient who gave thanks for medics decreased regardless of the way of access to the hospital. In particular, the number of thanks giving's decreased substantially (more than two time) in patients group who arrived of the same (SSD) (Table 2).

In analyzed period statistically significant differences between the group of emergency and plan out hospitalized patients not observed.

The correlation between the time of the provision of healthcare services and thanks giving was analyzed. Found that the examination at emergency department access to medical unit and doctor's examination in the room of patients up to $30 \mathrm{~min}$. increased number of thanksgivings more than twice in comparison with patients who have undergone this procedure after $30 \mathrm{~min}$. (SSD) (Table 3).

The time of a separate procedure did not effect on thanksgivings.

In period 2013-2015 compared with period 2004-2006 the part of patients who gave thanks for medics decreased (SSD) by the analysis of time of all procedures in first stage of hospitalization (Table 3 ).

The analysis of information provided for patients by doctors show that more thanks was from patients who thought the information was sufficient $(11,3 \%)$ in comparison with patients who felt it in the lack or in partly sufficient (4.9\%) (SSD).

The provision of information for hospitalized patients and it sufficient is important but not essential factor for pa- 
Table 5. The distribution of patients who gave thanks for medics depending on the yours satisfaction and results of healthcare *Not satisfied 167 (0, $2 \%)$

**Not satisfied 243 (0, $2 \%)$

\begin{tabular}{|c|c|c|c|c|c|c|c|c|c|c|c|c|c|}
\hline \multicolumn{14}{|c|}{ 2004-2006 yr. } \\
\hline \multicolumn{6}{|c|}{ Patients satisfaction with healthcare } & \multicolumn{8}{|c|}{ Results of healthcare } \\
\hline \multicolumn{6}{|c|}{$\mathrm{n}=\mathbf{8 3 3 3 3}$} & \multicolumn{8}{|c|}{$\mathrm{n}=\mathbf{8 3 3 3 3}$} \\
\hline \multicolumn{2}{|c|}{ Fully satisfied } & \multicolumn{2}{|c|}{ Satisfied } & \multicolumn{2}{|c|}{$\begin{array}{l}\text { Not satisfied or } \\
\text { didn't respond }\end{array}$} & \multicolumn{2}{|c|}{$\begin{array}{c}\text { Better than } \\
\text { expected }\end{array}$} & \multicolumn{2}{|c|}{$\begin{array}{c}\text { The same of } \\
\text { expected }\end{array}$} & \multicolumn{2}{|c|}{$\begin{array}{c}\text { The worse of } \\
\text { expected }\end{array}$} & \multicolumn{2}{|c|}{$\begin{array}{l}\text { Was not able to } \\
\text { specify or di- } \\
\text { dn't respond }\end{array}$} \\
\hline \multicolumn{2}{|c|}{$\mathrm{n}=63804$} & \multicolumn{2}{|c|}{$\mathrm{n}=18449$} & \multicolumn{2}{|c|}{$\mathrm{n}=1080 *$} & \multicolumn{2}{|c|}{$\mathrm{n}=36323$} & \multicolumn{2}{|c|}{$\mathrm{n}=35782$} & \multicolumn{2}{|c|}{$\mathrm{n}=491$} & \multicolumn{2}{|c|}{$\mathrm{n}=10737$} \\
\hline \multicolumn{2}{|c|}{ Gave thanks } & \multicolumn{2}{|c|}{ Gave thanks } & \multicolumn{2}{|c|}{ Gave thanks } & \multicolumn{2}{|c|}{ Gave thanks } & \multicolumn{2}{|c|}{ Gave thanks } & \multicolumn{2}{|c|}{ Gave thanks } & \multicolumn{2}{|c|}{ Gave thanks } \\
\hline $\mathrm{n}$ & $\%$ & $\mathrm{n}$ & $\%$ & $\mathrm{n}$ & $\%$ & $\mathrm{n}$ & $\%$ & $\mathrm{n}$ & $\%$ & $\mathrm{n}$ & $\%$ & $\mathrm{n}$ & $\%$ \\
\hline 10217 & 16,0 & 120 & 6,6 & 19 & 1,8 & 6698 & 18,4 & 3712 & 10,4 & 40 & 8,1 & 995 & 9,3 \\
\hline \multicolumn{14}{|c|}{ 2013-2015 yr. } \\
\hline \multicolumn{6}{|c|}{ Patients satisfaction with healthcare } & \multicolumn{8}{|c|}{ Results of healthcare } \\
\hline \multicolumn{6}{|c|}{$\mathrm{n}=\mathbf{1 2 7 7 5 0}$} & \multicolumn{8}{|c|}{$\mathrm{n}=\mathbf{1 2 7 7 5 0}$} \\
\hline \multicolumn{2}{|c|}{ Fully satisfied } & \multicolumn{2}{|c|}{ Satisfied } & \multicolumn{2}{|c|}{$\begin{array}{l}\text { Not satisfied or } \\
\text { didn't respond }\end{array}$} & $\begin{array}{r}\text { Bet } \\
\text { ex }\end{array}$ & $\begin{array}{l}\text { than } \\
\text { ted }\end{array}$ & $\begin{array}{l}\text { The } \\
\text { exp }\end{array}$ & $\begin{array}{l}\text { ne of } \\
\text { ted }\end{array}$ & The & $\begin{array}{l}\text { rse of } \\
\text { ted }\end{array}$ & $\begin{array}{l}\text { Was } \\
\text { spec } \\
\text { dn't }\end{array}$ & $\begin{array}{l}\text { able to } \\
\text { or di- } \\
\text { pond }\end{array}$ \\
\hline $\mathrm{n}=\mathrm{C}$ & & & & $\mathrm{n}=1$ & $18 * *$ & & 305 & $\mathrm{n}=$ & 377 & & & & 597 \\
\hline Gave & anks & $\mathrm{Ga}$ & anks & Gav & anks & Gav & lanks & Gave & lanks & $\mathrm{Ga}$ & lanks & Gav & anks \\
\hline $\mathrm{n}$ & $\%$ & $\mathrm{n}$ & $\%$ & $\mathrm{n}$ & $\%$ & $\mathrm{n}$ & $\%$ & $\mathrm{n}$ & $\%$ & $\mathrm{n}$ & $\%$ & $\mathrm{n}$ & $\%$ \\
\hline 8768 & 8,9 & 451 & 4,2 & 345 & 1,9 & 5471 & 12,2 & 3203 & 6,6 & 35 & 4 & 855 & 2,5 \\
\hline
\end{tabular}

tients satisfaction. This factor is more important for surgical patients (26).

The discusses of decisions of doctors with patients increased their thanks more than twice $-11,4 \%$ in comparison to witch such decisions didn't discussed or discussed some time $(4,2 \%)$. This is consistent with literature data $(27,28,29)$.

Significantly more thanksgivings were from patients who had possibility to consult with doctors about your health at any time $(11,5 \%)$ in comparison who such opportunity hadn't (4,0\%) (SSD).

A little bit more thanks was from patients who agreed to the provision of information to other about their health then from patients who didn't agree (11, $1 \%$ and $8 \%$ ).

According to all analyzed settings in both periods the trends remained the same, however the number of patients thanks in period 2013-2015 decreased (Table 4).

The analysis of correlation between satisfaction of healthcare of patients who gave thanks for medics and who didn't give show that the first group is more satisfying of healthcare (SSD) (Table 5).

The number of patients who gave thanks for medics is directly proportional to the results of healthcare (Table 5).

In assessing the results of the study, provided that the distribution of the patients who gave thanks for medics used the periods studied positions and groups remained similar.

During the period 2013-2015 patients who gave thanks for medics were less likely than period 2004-2006 due to the fact that the number of patients interviewed during the previous period was significantly higher, particularly in over 70 years group.

In addition, a 10-year increase KUH inpatients with more advanced disease and the condition more severe, grew up in patients' expectations and awareness for the medical profession and healthcare.

The fact that the changes in the analysis periods 20042006 and 2013-2015 number of patients who gave thanks 
for medics has only partial links to healthcare quality confirm the same number of dissatisfied patients $(0,2 \%$ and $0,2 \%$ ), of patients who didn't pick the hospital next time $(0,37 \%$ and $0,37 \%)$ and didn't recommend the hospital for friends and relatives $(0,37 \%$ and $0,37 \%)$.

By Schoenfelder (2) data the study of 39 German hospitals showed that $5,3 \%$ of patients didn't pick the hospital next time.

The data from this study are essentially similar to those of other countries.

\section{Conclusions}

1. Patients thanksgiving has confirmed the KUH provided healthcare for the majority of patients are appropriate to meet their expectations and they are satisfied with it.

2. Comparison of both analyzed periods has shown that over 10 years fell acknowledgments for medics.

3. Age, gender and social status had the impact on the number of acknowledgments - more thanksgiving was from women, patients 50-59 year age, retired and persons with disabilities.

4. The right cooperation between medics and patients, provision of healthcare information to patients increased the number of thanksgiving.

5. The number of patients who satisfied with healthcare results and meet their expectations directly correlated with number of patients who gave thanks for medics.

\section{References}

1. Janušonis $\mathrm{V}$. Tinkama sveikatos priežiūra. Pacientų nuomonè. Lietuvos bendrosios praktikos gydytojas, 2008; 12(6):421-427.

2. Schoenfelder T, Klewer J, Kugler J. Determinants of patient satisfaction: a study among 39 hospitals in a in-patient setting in Germany. International Journal for Quality in Healthcare 2011; 23:503-509.

http://dx.doi.org/10.1093/intqhe/mzr038

3. Sitzia J, Wood N. Patient satisfaction: a review of issues and concepts. Social Sciences in medicine 1997; 45:1829-1843. http://dx.doi.org/10.1016/S0277-9536(97)00128-7

4. Jackson JL, Chamberlin J, Kroenke K. Predictors of patient satisfaction. Social Science in Medicine 2001; 52:609-620. http://dx.doi.org/10.1016/S0277-9536(00)00164-7

5. Zhang Y, Rohrer J, Borders T. et al. Patient satisfaction, selfrelated health status and health confidence: on assessment of the utility of single-item questions. American Journal of Medical Quality 2007; 22:42-49.

http://dx.doi.org/10.1177/1062860606296329

6. Jaipaul CK, Rosenthal GE. Are older patients more satisfaction with hospital care than younger patients. Journal of General Internal Medicine 2003; 18:23-30. http://dx.doi.org/10.1046/j.1525-1497.2003.20114.x

7. Cohen G. Age and health status in a patient satisfaction survey. Social Science in Medicine 1996; 43:1085-1093.

8. Labarere J, Fourny M, Jean-Phillipe V. et al. Refinement and validation of a French in - patient experience questionnaire. International Journal of Healthcare Quality Assurance Inc. Leadersh Health Serv 2004; 17:17-25. http://dx.doi.org/10.1108/09526860410515909

9. Sofaer S, Crofton C, Goldstein E. et al. What do consumers want to know about quality of care in hospitals? Health Services Research 2005; 40:2057-2077.

10. Janušonis V. Sveikata ir valdoma sveikatos priežiūra. Klaipèda. S.Jokužio leidykla-spaustuvè, 2008.

11. Otani K, Waterman B, Faulkner KM. et al. Patient satisfaction: focusing on "Excellent". Journal of Healthcare Management 2009; 54:121-167.

12. Elliott MN, Kanouse DE, Edwards CA. et al. Components of care vary importance for overall patient reported experience by type of hospitalization. Medical Care 2009; 47:842-849. http://dx.doi.org/10.1097/MLR.0b013e318197b22a

13. Juran HM, Godfrey AB. Juran's Quality Handbook 5th end. New York: McGraw-Hill, 1999.

14. Pettlier MD, Ford RC, Heaton CP. Achieving Service Excellence: Strategies for Healthcare. Chicago II.: Health Administration Press, 2002.

15. Shirley ED, Sanders JO. Patient satisfaction: implications and predictors of success. The Journal of Bone and Joint Surgery 2013; 95:e69.

http://dx.doi.org/10.2106/JBJS.L.01048

16. Al-Abri R, Al-Balushi A. Patient satisfaction survey as a tool forwards quality improvement. Oman Medical Journal 2014; 29:3-7.

http://dx.doi.org/10.5001/omj.2014.02

17. Cleary PD, Edgman-Levitan S, Roberts M. et al. Patient evaluate their hospital care: a national survey. Health Aff (Milwood) 1991; 10(4):254-267.

http://dx.doi.org/10.1377/hlthaff.10.4.254

18. Lighter DE, Fair DC. Principles and Methods of Quality Management in Healthcare. Gaithersburg, Maryland: Aspen Publishers, Inc, 2000.

19. Frampton SM, Gilpin L, Charmel P. (). Putting Patients First. San-Francisco: Jossey-Bass, 2003.

20. LR pacientų teisių ir žalos sveikatai atlyginimo îstatymas. 1996 m. spalio 3 d. Nr. I-1562. Valstybės žinios. 1996; Nr.102; Publ. Nr.2317 (su vèlesniais pakeitimais).

21. European charter of patients' rights. Brussels, 2002.

22. Labarere J, Francois P, Aceguier P. et al. Development of a French inpatient satisfaction questionnaire. International Journal of Quality in Healthcare 2002; 13:99-108.

http://dx.doi.org/10.1093/intqhe/13.2.99

23. Sitzia J, Wood N. Response rate in patient satisfaction research: 
an analysis of 210 published studies. International Journal of Quality in Healthcare 1998; 10:311-317.

http://dx.doi.org/10.1093/intqhc/10.4.311

24. Quintana JM, Gonzalez N, Bilbao A. et al. Predictors of patients satisfaction with hospital care. BMC Health services research 2006; 6:102-102.

http://dx.doi.org/10.1186/1472-6963-6-102

25. Gonsalez N, Quintana JM, Bilbao A. et al. Development and validation, of an in-patient satisfaction questionnaire. International Journal of Quality in Healthcare 2005; 17:465-472. http://dx.doi.org/10.1093/intqhe/mzi067

26. Nguyen Thi PL, Briancon S, Empereur F. et al. Factors determining inpatient satisfaction with care. Social Science in Medicine 2002; 54:493-504. http://dx.doi.org/10.1016/S0277-9536(01)00045-4

27. Mira JJ, Rodriguez-Marin J, Tomas O. et al. Predictors of patient satisfaction in surgery. Surgery 2009; 145:536-541. http://dx.doi.org/10.1016/j.surg.2009.01.012

28. Rahmquist M, Bara A. Patient characteristics and quality dimensions related to patient satisfaction. International Journal for Quality in Healthcare, 2010.

29. Andaleeb SS. Determinants of customer satisfaction with hospitals: a managerial model. International Journal of Healthcare Quality Assuarance 1998; 11:183-203. http://dx.doi.org/10.1108/09526869810231541

\section{PACIENTU PASITENKINIMAS SVEIKATOS PRIEŽIŪRA: DE்KOJUSIŲ MEDIKAMS PACIENTU NUOMONĖS, POKYČIAI IR YPATUMAI V. Janušonis}

Raktažodžiai: sveikatos priežiūros kokybė, pacientų pasitenkinimas, sveikatos priežiūros vertinimas, pacientų padèkos.

Santrauka

Pacientų nuomonès vertinimas tampa būtinu sveikatos priežiūros organizacijų veiklos atributu. Pacientų nuomonè dalinai atspindi sveikatos priežiūros kokybę.

Darbo tikslas - įvertinti pacientų, pareiškusių padėkas medikams, nuomonę ir jos pokyčius bei ypatumus dèl pasitenkinimo sveikatos priežiūra, jos tinkamumo ir lūkesčių išsipildymo.

Tyrimo kontingentas ir metodika. Tęstinis tyrimas buvo vykdomas 2004-2015 m. Klaipėdos universitetinèje ligoninèje (KUL) ir apėmè 197755 pacientus. Pacientai užpildè paruoštus klausimynus (atsako dažnis 81,4 proc.).

Atskirai buvo analizuojami pacientų, dèkojusių medikams, užpildyti klausimynai 2004-2006 ir 2013-2015 m. periodais.

Rezultatai ir jų aptarimas. Dauguma dèkojusių medikams pacientų buvo 50-69 m. amžiaus, moterys, dirbantys. Sveikatos priežiūros paslaugų teikimo laikas, informacija pacientams, medikų bendravimas ir bendradarbiavimas su pacientais, pacientų pasitenkinimas sveikatos priežiūra didino dẻkojusių medikams pacientų skaičių. Pacientų padèkų medikams skaičius tiesioginio ryšio su sveikatos priežiūros kokybe neturèjo.

Išvados. Klaipėdos universitetinèje ligoninèje teikiama sveikatos priežiūra daugumai pacientų yra tinkama ir atitinkanti jų lūkesčius, jie ja yra patenkinti - raštu medikams dèkojo daugiau nei kas dešimtas pacientas.

Lyginant analizuojamus periodus per dešimt metų pacientų raštiškų padèkų medikams sumažèjo.

Lytis, amžius bei socialinė padètis turèjo įtakos pacientų padèkų skaičiui - dažniau medikams dėkojo moterys, brandaus amžiaus (50-69 m.) pacientai, pensininkai ir neigalieji.

Tinkamas medikų ir pacientų bendravimas, informacijos teikimas pacientams apie jų sveikatos priežiūrą didino pacientų padèkų skaičių.

Patenkintų sveikatos priežiūros paslaugomis pacientų, vertinančių sveikatos priežiūros rezultatus kaip atitikusius ar pranokusius jų lūkesčius dalis tiesiogiai koreliavo su dẻkojusių pacientų skaičiumi.

Adresas susirašinèti: janusonis@kul.lt

Gauta 2016-10-20 